\title{
Risk Factors for Spontaneous Abortion in Georgian Population
}

\author{
Manana Makharadze, (MD, PhD Student) \\ David Aghmashenebeli University of Georgia, Georgia \\ Revaz Sulukhia, MD, (PhD, Associate Professor) \\ Ivane Javakhishvili Tbilisi State University, Georgia \\ Mzia Tsiklauri, (PhD, Associate Professor) \\ Tesching University Geomedi, Georgia \\ Lali Melia (MD, PhD) \\ Gudushauri National Medical Center, Georgia \\ Iamze Taboridze (PhD, Associate Professor) \\ Grigol Robakidze University, Georgia
}

Doi:10.19044/esj.2019.v15n33p1 ～URL:http://dx.doi.org/10.19044/esj.2019.v15n33p1

\section{Abstract}

Background: Spontaneous abortion is a difficult problem for reproduction. This leads to the importance of studying risk factors. Since risk factors depend on demographic, ethnic, and environmental conditions of the population. The aim of our explore is to study the risk factors for spontaneous abortions and risk assessment among the population of Georgia. Methods: We retrospectively studied the clinical and laboratory features of 111 patients with identified spontaneous abortions who were treated at the Gudushauri clinic in 2015-2017. The control was carried out in the same period during the outpatient department of the Gudushauri clinic, 103 pregnant women who gave birth to live neonates. Research methods: history, clinical, clinical laboratory, immunological, morphological, bacteriological, ultrasound. The study of the following factors: age, education, family conditions, living conditions, bad habits, activities, working conditions, hereditary factors, accommodation, extragenital diseases, diet, physical activity, sleep hygiene, gynecological history, uterine deformities, medication during pregnancy, the results of a previous pregnancy, pregnancy complications, infections. Results: The risk of spontaneous abortion increases: Daily travel to long distance OR $=4.34(95 \%$ CI:1.45-3.03); Stress - OR=6.36(95\% CI:2.43-16.66); intermittent sleep $\mathrm{OR}=5.72(95 \% \mathrm{CI}: 2.15-15.19)$; Menstrual disorders OR=9.91(95\%CI:2.0148.94); hypertension $\mathrm{OR}=15.26(95 \% \mathrm{CI}: 1.03-27.24)$; anemia- $\mathrm{OR}=4.14(95 \%$ I:1.78-9.62); Flu during pregnancy - OR=6.24(95\% CI:1.63-23.90); leukocytosis $-\mathrm{OR}=1.32(95 \% \mathrm{CI}: 1.12-1.55)$ and decrease the placenta location 
in the base- $\mathrm{OR}=0.09(95 \% \mathrm{CI}: 0.02-0.47)$. Conclusion: Daily travel to long distance, flu, anemia, leukocytosis, stress, intermittent sleep during pregnancy, menstrual disorders, hypertension are the independent risk factors of spontaneous abortion in Georgian Population, relative chance of spontaneous abortion reduce: placenta at the base. The risk of spontaneous abortion in Georgian population is not determined by relationship status, bad habits and educational factors.

Keywords: Spontaneous Abortion, Pregnancy complications, Bad habits

\section{Introduction}

Spontaneous abortion is a difficult problem for reproduction. Its frequency is $8-20 \%$ of clinically confirmed pregnancy [Fergusson, D. M., et al. 2006 Wang X 2003 et al.]. The etiological factors include genetic abnormalities, infections, immunological and implant abnormalities, uterine and endocrine diseases, and lifestyle factors [Alexander J.2018, Pinar MH. 2018]. Patient's age, magnetic field and ion radiation(Delabaere A,2014), pesticide[Arbuckle, T. E., 2001], exposure, overweight[Yogev, Y. et al. 2009], Obesity increases after infertility treatment[Wang, J., et al. 2002, Metwally, M., et al. 2008]. risk factors for spontaneous abortions: factors for tobacco and cocaine consumption [Ness R.B., et al. 1999], coffee [Cnattingius, S., et al. 2000, Weng, X., et al. 2008], and folate deficiency, as well as Folic acid intake during pregnancy [George, L., et al. 2002]. Spontaneous abortion is associated with viral infections during pregnancy [Racicot K., et al. 2017]. Students with severe social conditions often experience pregnancy complications and abortion [Tesfaye, S., et al. 2014.]. Since risk factors depend on demographic, ethnic, and environmental conditions of the population, it is necessary to study these factors for all groups of the population. The aim of our study is to explore the risk factors for spontaneous abortions and risk assessment among the population of Georgia.

\section{Methods}

We retrospectively studied the clinical and laboratory features of 111 patients with identified spontaneous abortions who were treated at the Gudushauri National Medical Center in 2015-2017. The control was carried out in the same period during the out-patient department of the Gudushauri clinic, 103 pregnant women who gave birth to live neonates. Study design is observational, type is case-control study.

Inclusion criteria: Patients with spontaneous abortions, consent to participate in the study.

Exclusion criteria: genetic abnormalities of a pregnant woman or her partner. 
Research methods: history, clinical, clinical laboratory, immunological, morphological, bacteriological, ultrasound.

The study of the following factors: age, education, family conditions, living conditions, bad habits, activities, working conditions, hereditary factors, accommodation, extragenital diseases, diet, physical activity, sleep hygiene, gynecological history, uterine deformities, medication during pregnancy, the results of a previous pregnancy, pregnancy complications, infections.

Statistical analysis: for quantitative indicators, we measured the mean and standard deviation, the number and quantity of quality indicators. Significant difference in quantitative indicators was determined by the Student's test and by qualitative indicators - criteria $\mathrm{F}$ (Fisher). The difference was considered significant when $\mathrm{p}<0.05$. We used multivariate binary logistic regression analysis to calculate odds ratio, statistical analysis was performed using SPSS 22.

Results: The distribution of patients by age is shown in 1 Figure

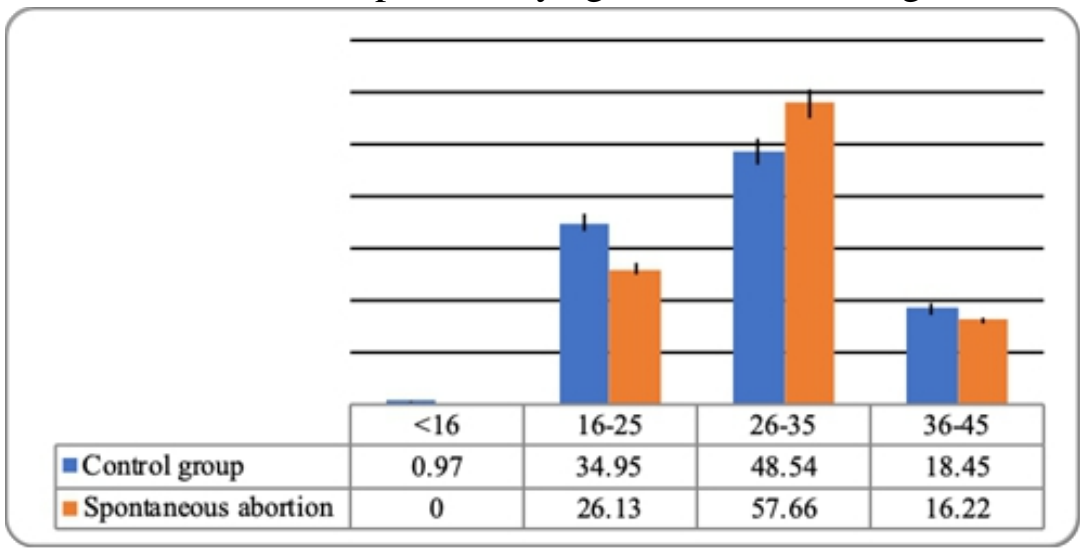

Figure 1. Distribution of patients by age $(\%)$

Among our pregnant women, 26-35 years prevail, and there are no significant differences between groups in the frequency of spontaneous abortions $(\mathrm{p}>0.05)$. Statistical evaluation factors of spontaneous abortions is given in table 1.

Table 1. Statistical assessment of the characteristics of pregnant women in the groups of spontaneous abortion and term labor.

\begin{tabular}{|c|l|c|c|c|c|c|c|}
\hline & & \multicolumn{2}{|c|}{$\begin{array}{c}\text { Control } \\
\text { group }\end{array}$} & \multicolumn{2}{c|}{$\begin{array}{c}\text { Spontaneous } \\
\text { abortion }\end{array}$} & \multirow{2}{*}{$\mathrm{F}$} & \multirow{2}{*}{$\mathrm{p}$} \\
\hline & & $\mathrm{N}$ & $\%$ & $\mathrm{~N}$ & $\%$ & & \\
\hline \multirow{2}{*}{$\begin{array}{c}\text { Educational } \\
\text { level }\end{array}$} & $\begin{array}{l}\text { University } \\
\text { degree }\end{array}$ & 64 & 62.14 & 74 & 66.67 & 0.48 & 0.4912 \\
\cline { 2 - 7 } & High school & 29 & 28.16 & 33 & 29.73 & 0.06 & 0.8009 \\
\hline $\begin{array}{c}\text { Living } \\
\text { conditions }\end{array}$ & unsatisfactory & 4 & 3.88 & 22 & 19.82 & 13.39 & 0.0003 \\
\cline { 2 - 8 } & Conflict & 1 & 0.97 & 2 & 1.80 & 0.26 & 0.6074 \\
\hline
\end{tabular}




\begin{tabular}{|c|c|c|c|c|c|c|c|}
\hline $\begin{array}{c}\text { Relationship } \\
\text { status }\end{array}$ & Single mother & 2 & 1.94 & 0 & 0.00 & 2.18 & 0.1415 \\
\hline \multirow[t]{2}{*}{ Bad habits } & $\begin{array}{l}\text { Coffee }>200 \mathrm{ml} \\
\text { per day. }\end{array}$ & 20 & 19.42 & 23 & 20.72 & 0.06 & 0.8132 \\
\hline & Smoking & 6 & 5.83 & 10 & 9.01 & 0.78 & 0.3786 \\
\hline \multirow{5}{*}{ Activity } & Student & 5 & 4.85 & 4 & 3.60 & 0.21 & 0.6506 \\
\hline & Schoolgirl & 2 & 1.94 & 0 & 0.00 & 2.18 & 0.1415 \\
\hline & Office work & 30 & 29.13 & 42 & 37.84 & 1.81 & 0.1794 \\
\hline & Physical labor & 7 & 6.80 & 2 & 1.80 & 3.33 & 0.0695 \\
\hline & Unemployed & 63 & 61.17 & 68 & 61.26 & 0.00 & 0.9886 \\
\hline \multirow{9}{*}{$\begin{array}{l}\text { Harmful } \\
\text { working } \\
\text { conditions }\end{array}$} & $\begin{array}{l}\text { Sitting for } 6 \\
\text { hours/day }\end{array}$ & 21 & 20.39 & 32 & 28.83 & 2.04 & 0.1544 \\
\hline & $\begin{array}{l}\text { Standing for } 6 \\
\text { hours/day }\end{array}$ & 7 & 6.80 & 10 & 9.01 & 0.35 & 0.5519 \\
\hline & $\begin{array}{l}\text { Lifting heavy } \\
\text { objects more } \\
\text { than } 9 \mathrm{~kg}\end{array}$ & 2 & 1.94 & 11 & 9.91 & 6.06 & 0.0146 \\
\hline & Vibration & 0 & 0.00 & 2 & 1.80 & 1.87 & 0.1727 \\
\hline & Production dust & 1 & 0.97 & 6 & 5.41 & 3.34 & 0.0690 \\
\hline & Chemicals & 0 & 0.00 & 2 & 1.80 & 1.87 & 0.1727 \\
\hline & Microclimate & 10 & 9.71 & 23 & 20.72 & 5.04 & 0.0258 \\
\hline & $\begin{array}{l}\text { Daily travel } \\
\text { long distance }\end{array}$ & 7 & 6.80 & 34 & 30.63 & 21.37 & $<0.0001$ \\
\hline & Hard work & 36 & 34.95 & 67 & 60.36 & 14.63 & 0.0002 \\
\hline \multirow{5}{*}{ Nutrition } & $\begin{array}{l}\text { Appetite } \\
\text { disturbance }\end{array}$ & 39 & 37.86 & 50 & 45.05 & 1.13 & 0.2891 \\
\hline & $\begin{array}{l}\text { Excess food } \\
\text { intake }\end{array}$ & 17 & 16.50 & 41 & 36.94 & 11.81 & 0.0007 \\
\hline & Poor nutrition & 20 & 19.42 & 15 & 13.51 & 1.36 & 0.2453 \\
\hline & $\begin{array}{l}\text { Get synthetic } \\
\text { fluids }\end{array}$ & 9 & 8.74 & 15 & 13.51 & 1.22 & 0.2708 \\
\hline & $\begin{array}{l}\text { Nutritional } \\
\text { disorder }\end{array}$ & 23 & 22.33 & 64 & 57.66 & 31.44 & $<0.0001$ \\
\hline \multirow{3}{*}{$\begin{array}{l}\text { Physical } \\
\text { activity }\end{array}$} & Low & 37 & 35.92 & 43 & 38.74 & 0.18 & 0.6722 \\
\hline & Average & 53 & 51.46 & 47 & 42.34 & 1.78 & 0.1835 \\
\hline & High & 10 & 9.71 & 23 & 20.72 & 5.04 & 0.0258 \\
\hline \multirow{3}{*}{ Sleep hygiene } & Wake up early & 19 & 18.45 & 18 & 16.22 & 0.18 & 0.6682 \\
\hline & Late to sleep & 11 & 10.68 & 19 & 17.12 & 1.84 & 0.1769 \\
\hline & $\begin{array}{l}\text { Intermittent } \\
\text { sleep }\end{array}$ & 42 & 40.78 & 66 & 59.46 & 7.66 & 0.0062 \\
\hline \multirow{6}{*}{$\begin{array}{c}\text { Extragenital } \\
\text { diseases }\end{array}$} & Obesity & 7 & 6.80 & 20 & 18.02 & 6.22 & 0.0134 \\
\hline & $\begin{array}{l}\text { Diabetes } \\
\text { melitus }\end{array}$ & 1 & 0.97 & 5 & 4.50 & 2.45 & 0.1188 \\
\hline & Hypothyroidism & 4 & 3.88 & 19 & 17.12 & 10.12 & 0.0017 \\
\hline & Atherosclerosis & 0 & 0.00 & 0 & 0.00 & - & - \\
\hline & Hypertension & 0 & 0.00 & 5 & 4.50 & 4.81 & 0.0293 \\
\hline & $\begin{array}{l}\text { Coronary heart } \\
\text { disease }\end{array}$ & 0 & 0.00 & 0 & 0.00 & - & - \\
\hline
\end{tabular}




\begin{tabular}{|c|c|c|c|c|c|c|c|}
\hline & $\begin{array}{l}\text { Gallbladder } \\
\text { disease }\end{array}$ & 3 & 2.91 & 7 & 6.31 & 1.38 & 0.2419 \\
\hline & Allergy & 18 & 17.48 & 38 & 34.23 & 7.98 & 0.0052 \\
\hline & $\begin{array}{l}\text { Chronic kidney } \\
\text { disease }\end{array}$ & 0 & 0.00 & 2 & 1.80 & 1.87 & 0.1727 \\
\hline & Varicose veins & 1 & 0.97 & 14 & 12.61 & 11.61 & 0.0008 \\
\hline & $\begin{array}{l}\text { Systemic } \\
\text { diseases }\end{array}$ & 0 & 0.00 & 7 & 6.31 & 6.87 & 0.0094 \\
\hline & Epilepsy & 1 & 0.97 & 4 & 3.60 & 1.62 & 0.2045 \\
\hline & Tuberculosis & 0 & 0.00 & 2 & 1.80 & 1.87 & 0.1727 \\
\hline \multirow{7}{*}{$\begin{array}{c}\text { Gynecologica } \\
1 \text { history }\end{array}$} & Menarche & 1 & 0.97 & 8 & 7.21 & 5.24 & 0.0231 \\
\hline & $\begin{array}{l}\text { Menstrual } \\
\text { disorders }\end{array}$ & 3 & 2.91 & 30 & 27.03 & 26.55 & $<0.0001$ \\
\hline & $\begin{array}{l}\text { Infertility over } 3 \\
\text { years }\end{array}$ & 4 & 3.88 & 3 & 2.70 & 0.23 & 0.6295 \\
\hline & $\begin{array}{l}\text { Inflammatory } \\
\text { diseases of the } \\
\text { pelvic cavity }\end{array}$ & 10 & 9.71 & 24 & 21.62 & 5.77 & 0.0171 \\
\hline & Uterine myoma & 4 & 3.88 & 14 & 12.61 & 5.37 & 0.0215 \\
\hline & $\begin{array}{l}\text { Uterine cavity } \\
\text { polyps }\end{array}$ & 2 & 1.94 & 2 & 1.80 & 0.01 & 0.9401 \\
\hline & $\begin{array}{l}\text { Ovarian } \\
\text { polycystic }\end{array}$ & 3 & 2.91 & 3 & 2.70 & 0.01 & 0.9264 \\
\hline $\begin{array}{c}\text { Uterine } \\
\text { anomalies }\end{array}$ & $\begin{array}{l}\text { Two uterous or } \\
\text { two uterine } \\
\text { wombs, uterine } \\
\text { tail }\end{array}$ & 0 & 0.00 & 0 & 0.00 & - & - \\
\hline $\begin{array}{l}\text { Genetic } \\
\text { factor }\end{array}$ & $\begin{array}{l}\begin{array}{l}\text { Congenital } \\
\text { thrombophilia }\end{array} \\
\end{array}$ & 1 & 0.97 & 8 & 7.21 & 5.24 & 0.0231 \\
\hline \multirow{10}{*}{$\begin{array}{l}\text { Previous } \\
\text { miscarriage }\end{array}$} & $\begin{array}{l}\text { Spontaneous } \\
\text { abortion } 1\end{array}$ & 18 & 17.48 & 19 & 17.12 & 0.00 & 0.9451 \\
\hline & $\begin{array}{l}\text { Spontaneous } \\
\text { abortion 2-4 }\end{array}$ & 4 & 3.88 & 7 & 6.31 & 0.64 & 0.4250 \\
\hline & $\begin{array}{l}\text { Spontaneous } \\
\text { abortion }>4\end{array}$ & 1 & 0.97 & 0 & 0.00 & 1.08 & 0.3003 \\
\hline & $\begin{array}{l}\text { medical } \\
\text { abortion } 1\end{array}$ & 11 & 10.68 & 18 & 16.22 & 1.39 & 0.2391 \\
\hline & $\begin{array}{l}\text { medical } \\
\text { abortion 2-4 }\end{array}$ & 7 & 6.80 & 4 & 3.60 & 1.11 & 0.2928 \\
\hline & $\begin{array}{l}\text { medical } \\
\text { abortion 4> }\end{array}$ & 1 & 0.97 & 7 & 6.31 & 4.27 & 0.0400 \\
\hline & $\begin{array}{l}\text { Antenatal fetal } \\
\text { death }\end{array}$ & 1 & 0.97 & 9 & 8.11 & 6.23 & 0.0133 \\
\hline & $\begin{array}{l}\text { Early neonatal } \\
\text { death }\end{array}$ & 3 & 2.91 & 0 & 0.00 & 3.30 & 0.0707 \\
\hline & $\begin{array}{l}\text { Complicated } \\
\text { Pregnancy }\end{array}$ & 0 & 0.00 & 2 & 1.80 & 1.87 & 0.1727 \\
\hline & $\begin{array}{l}\text { Difficult } \\
\text { childbirth }\end{array}$ & 0 & 0.00 & 7 & 6.31 & 6.87 & 0.0094 \\
\hline
\end{tabular}




\begin{tabular}{|c|c|c|c|c|c|c|c|}
\hline & $\begin{array}{l}\text { Cesarean } \\
\text { section }\end{array}$ & 33 & 32.04 & 36 & 32.43 & 0.00 & 0.9585 \\
\hline & $\begin{array}{l}\text { Postpartum } \\
\text { hemorrhage }\end{array}$ & 0 & 0.00 & 3 & 2.70 & 2.83 & 0.0937 \\
\hline & $\begin{array}{l}\text { Ectopic } \\
\text { pregnancy }\end{array}$ & 1 & 0.97 & 2 & 1.80 & 0.26 & 0.6074 \\
\hline \multirow{12}{*}{$\begin{array}{l}\text { Pregnancy } \\
\text { complications }\end{array}$} & Anemia & 17 & 16.50 & 63 & 56.76 & 44.29 & $<0.0001$ \\
\hline & Gestosis & 34 & 33.01 & 25 & 22.52 & 2.96 & 0.0870 \\
\hline & Hypertension & 1 & 0.97 & 8 & 7.21 & 5.24 & 0.0231 \\
\hline & Flu & 5 & 4.85 & 30 & 27.03 & 20.89 & $<0.0001$ \\
\hline & Heart failure & 0 & 0.00 & 0 & 0.00 & - & - \\
\hline & $\begin{array}{l}\text { Urinary Tract } \\
\text { Infection }\end{array}$ & 9 & 8.74 & 15 & 13.51 & 1.22 & 0.2708 \\
\hline & Injury & 2 & 1.94 & 14 & 12.61 & 9.09 & 0.0029 \\
\hline & $\begin{array}{l}\text { Bloody } \\
\text { discharge }\end{array}$ & 27 & 26.21 & 28 & 25.23 & 0.03 & 0.8695 \\
\hline & $\begin{array}{l}\text { Uterine } \\
\text { hypotoneus }\end{array}$ & 51 & 49.51 & 52 & 46.85 & 0.15 & 0.6980 \\
\hline & Intoxication & 0 & 0.00 & 3 & 2.70 & 2.83 & 0.0937 \\
\hline & $\begin{array}{l}\text { Anomalies of } \\
\text { fetal } \\
\text { development }\end{array}$ & 2 & 1.94 & 3 & 2.70 & 0.13 & 0.7143 \\
\hline & $\begin{array}{l}\text { Retarded fetal } \\
\text { growth }\end{array}$ & 0 & 0.00 & 5 & 4.50 & 4.81 & 0.0293 \\
\hline \multirow{8}{*}{ Medication } & Antibiotics & 6 & 5.83 & 15 & 13.51 & 3.59 & 0.0593 \\
\hline & Progesterone & 58 & 56.31 & 45 & 40.54 & 5.41 & 0.0210 \\
\hline & Corticosteroids & 6 & 5.83 & 4 & 3.60 & 0.19 & 0.6638 \\
\hline & Insulin & 0 & 0.00 & 3 & 2.70 & 2.83 & 0.0937 \\
\hline & $\begin{array}{l}\text { Drugs Acting U } \\
\text { pon the Central } \\
\text { Nervous } \\
\text { System. }\end{array}$ & 1 & 0.97 & 3 & 2.70 & 0.87 & 0.3523 \\
\hline & $\begin{array}{l}\text { Iodine- } \\
\text { containing } \\
\text { drugs }\end{array}$ & 9 & 8.74 & 33 & 29.73 & 15.89 & 0.0001 \\
\hline & Folic acid & 82 & 79.61 & 101 & 90.99 & 4.92 & 0.0276 \\
\hline & $\begin{array}{l}\text { vitamins of } \\
\text { group B }\end{array}$ & 39 & 37.86 & 37 & 33.33 & 0.48 & 0.4912 \\
\hline \multirow{3}{*}{$\begin{array}{l}\text { Obstetric } \\
\text { Ultrasound }\end{array}$} & placenta base & 18 & 17.48 & 8 & 7.21 & 5.36 & 0.0216 \\
\hline & Placenta side & 5 & 4.85 & 2 & 1.80 & 1.57 & 0.2116 \\
\hline & placenta-back & 39 & 37.86 & 45 & 40.54 & 0.16 & 0.6904 \\
\hline
\end{tabular}

As shown in the table, there are no significant differences between groups of spontaneous abortions and positive results in education, family environment and bad habits, the frequency of unsatisfactory living conditions compared with spontaneous abortions and control groups. 
Despite the fact that physical activity is not a risk factor, the abortion group is relatively high in frequency for those with more than $9 \mathrm{~kg}$ of cargo being transported and lead a physically active life. The influence of the production microclimate and daily long-distance travel has become significant.

In the control group, there was no effect on the effects of chemicals, including the presence of hypertension, chronic kidney disease, systemic diseases and complicated births. There was no sign of fetal growth.

Compared to the control of spontaneous abortion, there is a high frequency of over-feeding, eating habits and obesity. Sleep disturbances are relatively high - late sleep and intermittent sleep.

Among patients who have had a spontaneous abortion, the frequency of allergies and varicose diseases is relatively high, and more often in history: hypothyroidism, delayed menaeche, menstrual disorder, pelvic inflammatory diseases, uterine fibroids, more than 4 induced abortions, Prenatal death.

It is worth noting the high incidence of thrombophilia in the group of spontaneous abortions.

Among the current pregnancy complications, the abortion group is reliably high: anemia, hypertension, influenza, trauma.

At the next stage of the study, examine the blood test in both groups (Table 2).

Table 2. Assess the values of the complete blood count for spontaneous abortion and control

\begin{tabular}{|l|l|l|l|l|}
\hline & $\begin{array}{l}\text { Spontaneous } \\
\text { abortion } \mathrm{N}=111\end{array}$ & $\begin{array}{l}\text { Control group } \\
\mathrm{N}=103\end{array}$ & $\mathrm{t}$ & $\mathrm{P}$ \\
\cline { 2 - 5 } & Mean+Std. Dev. & Mean+Std. Dev. & & \\
\hline Hemoglobin & $110.85+13.29$ & $115.74+11.63$ & -2.87 & 0.0045 \\
\hline Erythrocytes $* 10^{12}$ cells $/ 1$ & $4.33+1.7$ & $4.71+1.9$ & 1.54 & 0.9379 \\
\hline Platelet count $\times 10^{9} / 1$ & $250.77+69.37$ & $259.11+57.19$ & -0.95 & 0.3409 \\
\hline Hematocrites & $32.23+3.87$ & $34.04+3.79$ & 3.44 & 0.0007 \\
\hline White blood cells count $\times 10^{9} / 1$ & $12.79+4.71$ & $10.4+2.35$ & 4.53 & $<0.0001$ \\
\hline Bands neutrophils count $\times 10^{9} / 1$ & $5.50+3.81$ & $3.56+1.59$ & 4.80 & $<0.0001$ \\
\hline Segmented Neutrophils $\times 10^{9} / 1$ & $72.83+6.55$ & $67.90+7.32$ & 5.17 & $<0.0001$ \\
\hline Lymphocytes $\times 10^{9} / 1$ & $14.30+5.94$ & $20.81+6.11$ & -7.89 & $<0.0001$ \\
\hline Monocites count $\times 10^{9} / 1$ & $6.00+2.04$ & $5.31+1.84$ & 2.60 & 0.0100 \\
\hline $\begin{array}{l}\text { Erythrocyte Sedimentation } \\
\text { Rate }\end{array}$ & $36.35+17.76$ & $28.20+18.70$ & 3.26 & 0.0013 \\
\hline Eosinophil count $\times 10^{9} / 1$ & $1.45+1.06$ & $2.39+2.33$ & -3.83 & 0.0002 \\
\hline
\end{tabular}

Hematocrit, leukocytes and ESR are significantly high with spontaneous abortions, and in the case of a good solution, hemoglobin is significantly higher.

No difference was observed for mean red blood cells. Compared with the control, both the hammer and the neutrophil segments, monitors and EMF, respectively, are hematocrit, as well as reduced monocytes and eosinophils. 
At the next stage of the study, using the characteristics for which a significant difference was made in spontaneous abortion and control groups, a regression analysis was performed (Table 3 ).

Table 3. Assessment of relative chances of spontaneous abortion

\begin{tabular}{|l|l|l|l|l|}
\hline & $\mathrm{p}$ & OR & 95\% C.I.for OR \\
\hline Daily travel long distance & 0.0088 & 4.34 & 1.45 & 13.03 \\
\hline Stress & 0.0002 & 6.36 & 2.43 & 16.66 \\
\hline Intermittent sleep & 0.0005 & 5.72 & 2.15 & 15.19 \\
\hline Menstrual disorders & 0.0049 & 9.91 & 2.01 & 48.94 \\
\hline Hypertension & 0.0479 & 15.26 & 1.03 & 227.24 \\
\hline Anemia & 0.0009 & 4.14 & 1.78 & 9.62 \\
\hline Flu during pregnancy & 0.0076 & 6.24 & 1.63 & 23.90 \\
\hline Placenta placement in based & 0.0043 & 0.09 & 0.02 & 0.47 \\
\hline Leukocytes & 0.0008 & 1.32 & 1.12 & 1.55 \\
\hline Constant & 0.1900 & 0.10 & & \\
\hline
\end{tabular}

As shown in the table, the relative chance of spontaneous abortion increases: Daily travel for a long distance, stress, intermittent sleep, menstrual disorders, hypertension, anemia, influenza during pregnancy, an increase in leukocytes; relative chance of spontaneous abortion reduce: placenta at the base.

\section{Discussion}

Spontaneous abortion is characterized by multi-factoriality. Socioeconomic risk factors indicate low economic conditions and incomplete secondary education[Zheng D., et al. 217]. According to this study, no significant differences were found between groups in terms of education. The incidence of spontaneous abortions was high in women with low income.

Among the risk factors is the age of the parents[de La Rochebrochard E., et al. 2002], which as argued here study did not confirm. It is noteworthy that the risk of housewives is low [de La Rochebrochard E., et al. 2002], which explains the stress and physical stress associated with stressful work. Compared to the control of a group of spontaneous abortions according to this materials, the frequency of unsatisfactory living conditions is relatively high. Predictors of spontaneous abortion is are considered to have severe physical work, foot and heavy weight [Banerjee B., et al. 2005]. This research suggests that the spontaneous abortion group is relatively high in the frequency of those who have more than $9 \mathrm{kgs}$ and carrying a physically active life. The significantly was the impact of the production microclimate and the daily traveling on a long distance, the high-risk factor for everyday travel.

Among the spontaneous abortion predictors, there are harmful habits: consumption of tobacco [Pineles, B. L., et al. 2014], coffee[Cnattingius, S., 
et al. 2000], alcohol[Inga Castillo, G. 2017]. According to other authors, five times a week of alcohol consumption and $375 \mathrm{ml}$ or more coffee per day increases the risk of spontaneous abortion and cigarettes are not increased risk [Rasch V., et al. 2003]. There is no reliable difference in the habit of spontaneous abortion and control in our population.

Increases interest in stress and emotional stress on pregnancy outcomes. Stress were associated with an increase in abortion risk[Arck P.C.,2001., Schenker M.B., et al. 1997], which confirmed this research, and in addition to the spontaneous abortion group, there is also a relatively high levels of sleep disorders - late sleep and intermittent sleep, which also affects the psychological condition. Obesity increases the risk of spontaneous abortion[Bell R. 2014, Boots C, et al. 2011], As demonstrated here, with a high risk of excessive nutrition, eating habits and obesity, but they do not have an independent prognostic significance compared to the controlled abortion grouping.

The concept of taking folic acid during pregnancy varies, according to some studies, it reduces the risk of spontaneous abortion, and in some it increases it [Bailey LB, et al. 2005]. In our study group, the frequency of folic acid intake is higher compared to the control, but it does not have a prognostic value.

Genetic factors are important for thrombophilia, which is the risk of repeated spontaneous abortion [Pritchard A.M., et al. 2016]. This paper showed a high level of thrombophilia in the group of spontaneous abortion.

The risk factors are - mental disorders, urinary tract infections, at least one episode of abortion and sexual activity before the age 18[Inga Castillo, G.2017]; There are associations spontaneous abortions and hypercholesterolemia, hypertension and 2 types of diabetes[Horn J,2019]. Pregnant women with subclinical hypothyroidism have a high risk of spontaneous abortions. However, according to some authors, spontaneous abortions are not associated with mass indexes, congenital anomalies in history, ectopic pregnancy, thyroid dysfunction and hypertension[Poorolajal, J., et al. 2014]. As demonstrated here, in spontaneous abortion group, the frequency of allergies and varicose diseases is significantly high, and in the anamnesis more frequently: hypothyroidism, Delayed Menarche, Menstrual disorders, pelvic inflammatory diseases, fibroids, more than 4 medical abortions, and antenatal death of the fetus. From pregnancy complications women are significantly high: anemia, arterial hypertension, flu, trauma.

Among the risk facts are the introduction of antibiotics such as macrolides (except erythromycin), chinolines[Padberg S, et al. 2014], tetracycline, sulphanlamymides and metronidazole associated with increased risk of spontaneous abortion in the early period of pregnancy [Muanda, F.T., 
et al., 2017, Bar-Oz B. et al. 2012]. This paper shows that, the frequency of antibiotics is undoubtedly higher in the abortion group.

\section{Conclusion}

Daily travel to long distance, flu, anemia, leukocytosis, stress, intermittent sleep during pregnancy, menstrual disorders, hypertension are the independent risk factors of spontaneous abortion in Georgian Population, relative chance of spontaneous abortion reduce: placenta at the base. The risk of spontaneous abortion in Georgian population is not determined by relationship status, bad habits and educational factors.

\section{References:}

1. Alexander J. Dobson S \& Jayaprakasan K M (2018) Aetiology of recurrent miscarriage and the role of adjuvant treatment in its management: a retrospective cohort review, Journal of Obstetrics and Gynaecology,

2. Arbuckle, T. E., Lin, Z., \& Mery, L. S. (2001). An exploratory analysis of the effect of pesticide exposure on the risk of spontaneous abortion in an Ontario farm population. Environmental health perspectives, 109(8), 851 .

3. Arck, P. C. (2001). Stress and pregnancy loss: role of immune mediators, hormones and neurotransmitters. American Journal of Reproductive Immunology, 46(2), 117-123.

4. Bailey LB, Berry RJ.(2005)Folic acid supplementation and the occurrence of congenital heart defects, orofacial clefts, multiple births, and miscarriage. Am J Clin Nutr ;81:1213-1217

5. Banerjee B.Dey T. K, Chatterjee P. Work (2005). Related Physical Exertion and Spontaneous Abortion. Indian $\mathrm{J}$ Public Health. 49(4):248-9.

6. Bar-Oz B, Weber-Schoendorfer C, Berlin M, (2012). The outcomes of pregnancy in women exposed to the new macrolides in the first trimester: a prospective, multicentre, observational study. Drug Saf.35:589-98

7. Bell R. (2014) Maternal body mass index increasing above 20 is associated with increased risk of miscarriage, stillbirth, neonatal death and postneonatal death. Evid Based Med. 19:237-238

8. Boots C, Stephenson $\mathrm{MD}(2011)$. Does obesity increase the risk of miscarriage in spontaneous conception: a systematic review. Semin Reprod Med. 29(6):507-13

9. Cnattingius, S., Signorello, L. B., Annerén, G., Clausson, B., Ekbom, A., Ljunger, E., ... \& Granath, F. (2000). Caffeine intake and the risk 
of first-trimester spontaneous abortion. New England Journal of Medicine, 343(25), 1839-1845.

10. de La Rochebrochard, E. and Thonneau, P. (2002). Paternal age and maternal age are risk factors for miscarriage; results of a multicentre European study. Human Reproduction, 17(6), 1649-1656.

11. Delabaere, A., Huchon, C., Deffieux, X., Beucher, G., Gallot, V., Nedellec, S., ... \& Barasinski, C. (2014). Epidemiology of loss pregnancy. Journal de gynecologie, obstetrique et biologie de la reproduction, 43(10), 764-775. ${ }^{1}$

12. Fergusson, D. M., John Horwood, L., \& Ridder, E. M. (2006). Abortion in young women and subsequent mental health. Journal of Child Psychology and Psychiatry, 47(1), 16-24.

13. George, L., Mills, J. L., Johansson, A. L., Nordmark, A., Olander, B., Granath, F., \& Cnattingius, S. (2002). Plasma folate levels and risk of spontaneous abortion. Jama, 288(15), 1867-1873.

14. Horn J, Tanz LJ, Stuart JJ, Markovitz AR, Skurnik G, Rimm EB, Missmer SA, Rich-Edwards JW(2019) Early or late pregnancy loss and development of clinical cardiovascular disease risk factors: a prospective cohort study.BJOG. 126(1):33-42

15. Inga Castillo, G. (2017). Factores asociados a aborto en mujeres jóvenes de 19 a 29 años de edad del hospital Militar Central en el año 2016.

16. Metwally, M., Ong, K. J., Ledger, W. L., \& Li, T. C. (2008). Does high body mass index increase the risk of miscarriage after spontaneous and assisted conception? A meta-analysis of the evidence. Fertility and sterility, 90(3), 714-726.

17. Muanda, F. T., Sheehy, O., \& Bérard, A. (2017). Use of antibiotics during pregnancy and risk of spontaneous abortion. CMAJ: Canadian Medical Association journal = journal de l'Association medicale canadienne, 189(17), 625-633.

18. Ness, R. B., Grisso, J. A., Hirschinger, N., Markovic, N., Shaw, L. M., Day, N. L., \& Kline, J. (1999). Cocaine and tobacco use and the risk of spontaneous abortion. New England Journal of Medicine, 340(5), 333-339.

19. Padberg S, Wacker E, Meister R,(2014). Observational cohort study of pregnancy outcome after first-trimester exposure to fluoroquinolones. Antimicrob Agents Chemother 58:4392-8

20. Pinar, M. H., Gibbins, K., He, M., Kostadinov, S., \& Silver, R. (2018). Early pregnancy losses: review of nomenclature, histopathology, and possible etiologies. Fetal and pediatric pathology, 37(3), 191-209.

21. Pineles, B. L., Park, E., \& Samet, J. M. (2014). Systematic review and meta-analysis of miscarriage and maternal exposure to tobacco smoke 
during pregnancy. American journal of epidemiology, 179(7), 807823.

22. Poorolajal, J., Cheraghi, P., Cheraghi, Z., Ghahramani, M., \& Doosti Irani, A. (2014). Predictors of miscarriage: a matched case-control study. Epidemiology and health, 36, e2014031.

23. Pritchard AM, Hendrix PW, Paidas MJ. (2016) Hereditary Thrombophilia and Recurrent Pregnancy Loss.Clin Obstet Gynecol. 59(3):487-97.

24. Racicot, K., \& Mor, G. (2017). Risks associated with viral infections during pregnancy. The Journal of clinical investigation, 127(5), 15911599.

25. Rasch V. (2003)Cigarette, alcohol, and caffeine consumption: risk factors for spontaneous abortion.. Acta Obstet Gynecol Scand. Feb; 82(2):182-8.

26. Schenker MB, Eaton M, Green R,Samuels S.( 1997) Self-reported stress and reproductive health of female lawyers. J Occup Environ Med;39:556-68.

27. Tesfaye, S., Jibat, N. (2014). Situational Assessment of Off-Campus Resident Female Students of Jimma Teacher Training College (Jttc) in Focus, Oromia. European Scientific Journal, 10(32).

28. Wang, J. X., Davies, M. J., \& Norman, R. J. (2002). Obesity increases the risk of spontaneous abortion during infertility treatment. Obesity research, 10(6), 551-554.

29. Wang, X., Chen, C., Wang, L., Chen, D., Guang, W., French, J., \& Reproductive Health Study Group. (2003). Conception, early pregnancy loss, and time to clinical pregnancy: a population-based prospective study. Fertility and sterility, 79(3), 577-584.

30. Weng, X., Odouli, R., \& Li, D. K. (2008). Maternal caffeine consumption during pregnancy and the risk of miscarriage: a prospective cohort study. American journal of obstetrics and gynecology, 198(3), 279-e1.

31. Yogev, Y., \& Catalano, P. M. (2009). Pregnancy and obesity. Obstetrics and gynecology clinics of North America, 36(2), 285-300.

32. Zheng D, Li C, Wu T, Tang K. (2017) Factors associated with spontaneous abortion: a cross-sectional study of Chinese populations. Reproductive health. Dec;14(1):33. 